\title{
A quick and low-cost PCR-based assay for Candida spp. identification in positive blood culture bottles
}

Hemílio Xafranski ${ }^{1 \dagger}$, Analy SA Melo ${ }^{1 \dagger}$, Antonia M Machado ${ }^{3}$, Marcelo RS Briones ${ }^{2}$ and Arnaldo L Colombo ${ }^{1 *}$

\begin{abstract}
Background: Differences in the susceptibility of Candida species to antifungal drugs make identification to the species level important for clinical management of candidemia. Molecular tests are not yet standardized or available in most clinical laboratories, although such tests can reduce the time required for species identification, as compared to the conventional culture-based methods. To decrease laboratory costs and improve diagnostic accuracy, different molecular methods have been proposed, including DNA extraction protocols to produce pure DNA free of PCR inhibitors. The objective of this study was to validate a new format of molecular method, based on the internal transcribed spacer (ITS) of the rDNA gene amplification followed by sequencing, to identify common and cryptic Candida species causing candidemia by analyzing DNA in blood culture bottles positive for yeasts.

Methods: For DNA extraction, an "in-house" protocol based on organic solvent extraction was tested. Additional steps of liquid nitrogen incubation followed by mechanical disruption ensured complete cell lysis, and highly pure DNA. One hundred sixty blood culture bottles positive for yeasts were processed. PCR assays amplified the ITS region. The DNA fragments of 152 samples were sequenced and these sequences were identified using the GenBank database (NCBI). Molecular yeast identification was compared to results attained by conventional method.

Results: The organic solvent extraction protocol showed high reproducibility in regards to DNA quantity, as well as high PCR sensitivity (10 pg of C. albicans DNA and 95\% amplification on PCR). The identification of species at the molecular level showed $97 \%$ concordance with the conventional culturing method. The molecular method tested in the present study also allowed identification of species not commonly implicated in human infections.

Conclusions: This study demonstrated that our molecular method presents significant advantages over the conventional yeast culture identification method by providing accurate results within 24 hours, in contrast to at least 72 hours required by the automated conventional culture method. Additionally, our molecular method allowed the identification of mixed infections, as well as infections due to emergent fungal pathogens. This economical DNA extraction method developed in our laboratory provided high-quality DNA and $60 \%$ cost savings compared to commercial methods.
\end{abstract}

Keywords: Candidemia, Molecular diagnosis, ITS region sequencing, Fungal DNA extraction

\footnotetext{
* Correspondence: arnaldolcolombo@gmail.com

${ }^{+}$Equal contributors

'Laboratório Especial de Micologia, Departamento de Medicina, Universidade Federal de São Paulo, Rua Pedro de Toledo 6695 andar, São Paulo, SP, Brazil Full list of author information is available at the end of the article
} 


\section{Background}

Nosocomial candidemia remains a frequent cause of morbidity and mortality, mainly among immunocompromised and intensive care (ICU) patients [1-3]. Mortality remains high, mainly due to the severity of underlying conditions associated with candidemia, as well as limitations in the conventional tools available for early diagnosis of this infection [4-6].

The clinical signs of sepsis due to candidemia are nonspecific, and diagnosis generally relies on conventional blood culture, which is often delayed and presents sensitivity lower than $70 \%[7,8]$. Early diagnosis of this infection is essential for proper antifungal therapy, and delays of more than 12 hours in the administration of antifungal agents may substantially increase mortality [9].

PCR methods for the diagnosis of Candida bloodstream infections are not yet internationally standardized, and divergent results may be obtained when different parameters are used to perform the test. Indeed, there are still controversies regarding the selection of biological material to be tested (whole blood, plasma or serum), various protocols for DNA extraction, the gene target to be analyzed, the PCR assay used (conventional, nested, PCR-RFLP or real time), the number of cycles, the detection limit and the parameters used for sequences analysis [10-16]. In the absence of commercial systems largely validated in multicenter studies, "in-house" PCR based methods remain used worldwide for the diagnosis of candidemia.

In the present study, we validated a new format of molecular method based on ITS-PCR followed by sequencing to identify common and cryptic Candida species causing candidemia by analyzing fungal DNA in yeast-positive blood culture bottles using a rapid and accurate molecular method. We also standardized a lowcost method for DNA extraction, developed "in-house", that yielded highly purified DNA and provided 60\% cost savings compared to the commercial methods.

\section{Results and discussion Fungal DNA extraction}

DNA was purified from blood samples using an extraction method described below that yielded high-quality DNA (high purity with respect to proteins and salt, optical density (OD) $260 / 280$ and $260 / 230$ with rate values $\geq 1.8$ ) and decreased the effect of PCR inhibitors such as hemoglobin and some components of the culture medium.

It has been well documented that the fungal cell wall is an important obstacle to nucleic acid extraction and that the effectiveness of the cell lysis and DNA extraction highly influences the sensitivity of PCR assays $[17,18]$.

Our methodology included two important cell lysis steps: freezing the sample with liquid nitrogen and agitation with glass beads. Both procedures have been successfully used by other authors to attain fungal cell lysis and DNA extraction [18-20]. We used the $\mathrm{Brazol}^{\odot}$ reagent (guanidine thiocyanate), an inexpensive compound that is able to disrupt cell membranes, fragment chromosomes, and prevent DNA from being trapped in clinical sample residues, reducing the activity of PCR inhibitors [21].

Our extraction protocol was designed to extract both intracellular and extracellular DNA from the sample [22]. This protocol was standardized by testing negative blood culture bottles and C. albicans-spiked blood culture as negative and positive controls, respectively (data not shown).

This "in-house"-developed DNA extraction method provided approximately $60 \%$ cost savings compared to commercial methods.

\section{PCR for fungal ITS amplification and sequencing}

Of 160 DNA samples extracted from blood culture bottles positive for yeasts, successful amplification of the ITS was achieved in 152 samples (95\%) using our PCR methodology. Our method yielded fragments of 400-700 bp (see Figure 1A).

The ITS 1, ITS 2 and $5.8 \mathrm{~S}$ regions of rDNA have already been well documented as a reliable target for amplification and sequencing, useful for discriminating between medically important yeasts $[10,23]$. Within the ITS rDNA region, we selected the universal fungalspecific primers ITS1 and ITS4 because our preliminary studies demonstrated that these primers were more specific for fungal DNA, presenting lower levels of crossreaction with human DNA than other primers. We also used a high hybridization temperature $\left(58^{\circ} \mathrm{C}\right)$, which allowed the specific amplification of fungal DNA. The ITS sequences were obtained using the same primers used in the PCR assay. Results from BLASTn that provided an e-value less than $10^{-5}$ and a maximum identity higher than $98 \%$ were considered reliable for identification of Candida species.

Only 8 infection samples could not be amplified by our PCR method, as follows: 2 samples of C. albicans, 2 samples of C. parapsilosis, 2 samples of C. tropicalis, 1 sample of C. pelliculosa (Pichia anomala) and 1 mixed infection sample of $C$. parapsilosis and C. guilliermondii. To check for the presence of PCR inhibitors, $C$. albicans ATCC 24433 genomic DNA was added to each sample prior to the PCR assay. These samples could not be amplified despite the addition of $C$. albicans DNA (Figure 1B). These findings suggest that the cause of negative PCR results was neither the detection limit of yeast DNA for the test nor insufficient DNA quantities in the sample. Rather, it was caused by the presence of PCR inhibitors that were not removed by Brazol during DNA extraction or by the addition of bovine serum albumin (BSA) to the PCR assay.

The presence of PCR inhibitors such as hemoglobin, lactoferrin and sodium polyanetholesulfonate from 


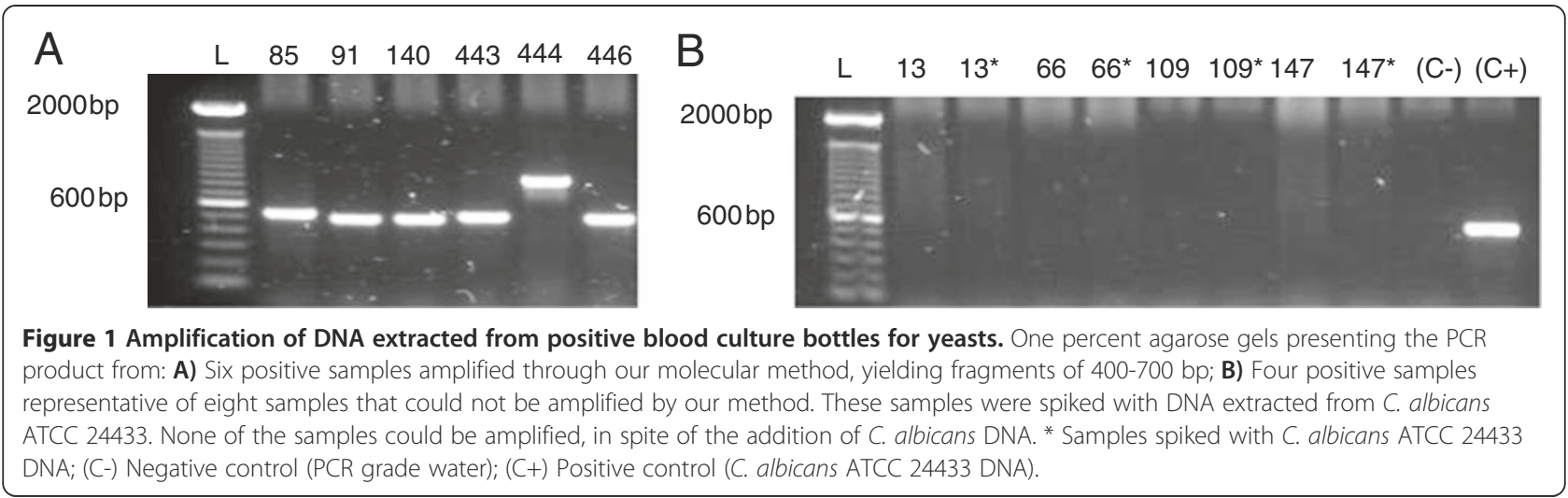

erythrocytes, leukocytes and blood culture media, respectively, may explain false negative results generated along DNA amplification from clinical samples [24]. The inhibitory effect of hemoglobin and lactoferrin seems to be related to the ability of these proteins to release iron ions. The inhibitory effect of iron ions appears to act directly on the DNA polymerase by competing with the template. Lactoferrin also appears to interact with nucleic acids. Al-Soud and Radstrom [24] tested several amplification facilitators in the presence of hemoglobin and lactoferrin. BSA was the most efficient compound in reducing inhibition of amplification, due to its binding efficiency. Consequently, BSA is often used to increase the sensitivity of PCR amplification from clinical samples [24-26].

With the exception of the 8 samples that were not amplified in this study, the addition of BSA to the PCR assay allowed us to amplify most of the samples.

\section{Comparison between the conventional culture-based Candida spp. identification method and our molecular method}

The identification of Candida spp. obtained by the conventional culture-based and molecular methods is shown on Table 1. The results of the genotypic identification method correlated highly with the conventional culturebased identification method (97\%). It is important to stress that discordant identifications corresponded to cryptic species (e.g., the C. haemulonii, C. intermedia and $C$. parapsilosis species complex). These species were not accurately identified by the conventional method but were identified by the present PCR- and sequencing-based method. In addition, our molecular method was able to identify one episode of mixed infection (C. albicans and C. glabrata), while the conventional culture-based method recognized only $C$. albicans in the mixed infection. This difference between assays is most likely due to the unviability of C. glabrata cells for culture, rendering them undetectable by the conventional culture-based method.
However, the persistence of detectable DNA in the sample allowed for successful identification by the molecular method. In contrast, one episode of mixed infection caused by C. glabrata and C. albicans was recognized by the culture method, while our molecular method identified only C. albicans. This anomaly was most likely the result of low burden of C. glabrata in the sample, especially in the low volume of extracted DNA used for PCR assay. As noted by Pfeiffer et al. [22], despite the high sensitivity

\section{Table 1 Comparison of phenotypic and genotypic identification of yeasts obtained from positive blood culture bottles}

\begin{tabular}{|c|c|c|c|}
\hline \multicolumn{2}{|c|}{ Phenotypic identification } & \multicolumn{2}{|l|}{ Genotypic identification } \\
\hline Species & $\begin{array}{l}\text { Number of } \\
\text { identified } \\
\text { samples }\end{array}$ & Species & $\begin{array}{l}\text { Number of } \\
\text { identified } \\
\text { samples }\end{array}$ \\
\hline \multirow[t]{2}{*}{ C. albicans } & 41 & C. albicans & 40 \\
\hline & & C. albicans + C. glabrata & 1 \\
\hline C. glabrata & 28 & C. glabrata & 28 \\
\hline \multirow[t]{3}{*}{ C. guilliermondii } & 4 & $\begin{array}{l}\text { Meyerozyma } \\
\text { guilliermondii }\end{array}$ & 2 \\
\hline & & Clavispora lusitaniae & 1 \\
\hline & & C. intermedia & 1 \\
\hline C. krusei & 15 & Issatchenkia orientalis & 15 \\
\hline C. Iusitaniae & 1 & Clavispora lusitaniae & 1 \\
\hline C. norvegensis & 1 & Pichia norvegensis & 1 \\
\hline \multirow[t]{2}{*}{$\begin{array}{l}\text { C. parapsilosis } \\
\text { (sensu lato) }\end{array}$} & 34 & $\begin{array}{l}\text { C. parapsilosis (sensu } \\
\text { stricto) }\end{array}$ & 27 \\
\hline & & C. orthopsilosis & 7 \\
\hline C. pelliculosa & 1 & C. haemulonii & 1 \\
\hline C. tropicalis & 26 & C. tropicalis & 26 \\
\hline $\begin{array}{l}\text { C. glabrata }+C . \\
\text { albicans }\end{array}$ & 1 & C. albicans & 1 \\
\hline Total & 152 & & 152 \\
\hline
\end{tabular}

Issatchenkia orientalis: teleomorph of C. krusei; Clavispora lusitaniae: teleomorph of C. lusitaniae; Meyerozyma guilliermondii: teleomorph of $C$. guilliermondii; Pichia norvegensis: teleomorph of C. norvegensis. 
of conventional PCR, a minimum of $10 \mathrm{CFU} / \mathrm{ml}$ is generally required to detect fungal DNA.

In contrast with methodologies that adopt real-time PCR and/or nested PCR $[27,28]$, our method is not limited to the use of a small number of probes or primers. Our method also provides accurate identification of emergent pathogens and novel sequence variants for which species-specific primers or probes have not yet been validated.

Through this molecular method, after the bottles with positive cultures were detected, we were able to extract DNA from the blood cultures and accurately identify fungal species within 24 hours, while the conventional non-automated method would take at least 72-96 hours [29]. Morrell et al. [6] has previously demonstrated that a 12-hour delay in the initiation of antifungal treatment is sufficient time to double mortality in patients with candidemia. By using the ITS-PCR and sequencing method developed in this study, it is possible to reduce the time required to identify the causal yeast species in an infection by 48 hours compared to the conventional culture-based method.

\section{Performance of ITS-PCR and sequencing compared to other molecular methods}

The ITS-PCR and sequencing method validated in our laboratory showed low-cost, reliable and accurate Candida species identification; it yielded accurate final identification in 152 out of 160 (95\%) blood cultures tested. The reproducibility of the assay was $100 \%$ as checked by a pilot study testing negative blood culture bottles spiked with cultured Candida spp. cells (data not shown). Our molecular method allowed the identification of rare and cryptic species, such as $C$. intermedia, C. haemulonii and $C$. orthopsilosis (the last one is a species of the $C$. parapsilosis complex). Identification was accomplished with tools and techniques that are accessible to routine laboratories, including a low-cost "in-house" DNA extraction protocol and an automatic sequencer that uses the Sanger method.

A large variety of PCR-based methods has been applied to identify candidemia in blood culture bottles, but most of these methods used specific primers and probes that may potentially limit the number of species that can be identified. Shin et al. has described a clinically useful PCR method, followed by identification with speciesspecific probes that could detect only the five most common Candida species in 73 blood culture bottles from 31 candidemic patients [29]. These probes could not identify cryptic species of the C. parapsilosis complex, C. orthopsilosis and C. metapsilosis.

Other authors have developed semi-nested or multiplex PCR methods involving the amplification of yeast rDNA regions, resulting in fragments of different sizes for species identification. These methods were not able to differentiate between all the species tested, including the rare and cryptic species, especially the ones classified in species complex, such as $C$. parapsilosis and C. guilliermondii [10,30-32].

Other PCR-based methods followed by DNA sequencing have been successfully developed. However, these studies have used commercial methods for DNA extraction, which makes this process more expensive than our "in-house"-developed DNA extraction method [33,34]. Additionally, Quiles-Melero et al. used a PCR-based methodology coupled with pyrosequencing [34]. The authors reported accurate Candida spp. identification in all 47 blood culture bottles tested, yielding 100\% correlation with the conventional method. However, pyrosequencing methodology is not available for candidemia diagnosis in most medical centers.

\section{Conclusions}

Several studies have been published describing the use of conventional, nested or real-time PCR in positive blood culture bottles to identify yeast species; however, no molecular methodology has been broadly adopted for the identification of yeast species in modern clinical laboratories. Even direct PCR of blood from patients with suspected candidemia would provide more rapid species identification. Unfortunately, this methodology yields low positivity due to the low fungal burdens usually present in whole blood samples $[15,22,35,36]$.

In the present study, we described and validated a new format for a molecular-based method of yeast identification. This method is based on ITS-PCR followed by sequencing to identify common, rare and cryptic Candida species that cause candidemia and are present in yeastpositive blood culture bottles. This molecular method for the identification of Candida spp. had a significant advantage over the conventional culture-based identification method by providing accurate results within 24 hours, in contrast to at least 72 hours required by the automated conventional culture. The molecular method developed in this study additionally provided identification of mixed infections as well as infections due to emergent fungal pathogens. Furthermore, the low-cost DNA extraction method developed in our laboratory provided high-quality DNA and 60\% cost-savings compared to commercial methods.

\section{Methods}

Selection of biological samples and controls for PCR

We selected a total of 160 yeast-positive blood culture bottles among 405 bottles of the BACTEC system yielding yeasts that were sequentially processed in the clinical laboratory of the Hospital São Paulo, Universidade Federal de São Paulo, between October 2008 and 
February 2012. Immediately after confirmation of yeast growth in blood cultures, aliquots from each bottle were taken for conventional fungal culture and microorganism identification. Finally, aliquots of 3-4 mL of each bottle processed during the period were stored at $-20^{\circ} \mathrm{C}$ for further PCR analysis.

The selection of samples for further PCR assays aimed to include cultures representative of most clinically relevant species of Candida based on the initial phenotypic identification obtained in our clinical laboratory of the yeasts growing in blood cultures. Based on the initial identification of yeast colonies generated by the ID 32 system and complemented by the micromorphology findings, 152 cultures were studied. These cultures included the most common species that cause candidemia: $C$. albicans (41/27.1\%), C. parapsilosis (34/22.5\%), C. tropicalis (26/17.2\%), C. glabrata (28/18.5\%), C. krusei (15/9.9\%), and C. guilliermondii (4/2.6\%). In addition, we selected 3 cases representative of candidemic episodes due to unusual pathogens as identified by the ID-32 system: C. pelliculosa (1/0.7\%), C. lusitaniae (1/0.7\%) and C. norvegensis (1/0.7\%). We also included one case of mixed infection caused by $C$. albicans and C. glabrata (1/0.7\%).

Finally, as negative controls for the Candida PCR assay, we included DNA samples from blood cultures representative of sepsis due to Gram-positive (10 samples) and Gram-negative bacteria (10 samples), as well as 10 negative blood cultures. Genomic DNA extracted from the reference strain Candida albicans ATCC 24433 was used as a positive control.

\section{DNA extraction from blood culture bottles}

DNA was extracted from all samples according to the method adapted from Sandhu et al. [21]. For this procedure, $300 \mu \mathrm{L}$ of each sample and $200 \mu \mathrm{L}$ of glass beads were added to a $1.5 \mathrm{~mL}$ microtube, incubated in liquid nitrogen for 2 minutes and vigorously shaken for 3 cycles of 45 seconds in a FastPrep homogenizer at speed 5.0. After cooling the tubes on ice, $600 \mu \mathrm{L}$ of room temperature Brazol was added and the tubes were vortexed. Subsequently, $130 \mu \mathrm{L}$ of cold chloroform was added, and the tubes were shaken again. The samples were then centrifuged at $20,000 \times g$, at $8^{\circ} \mathrm{C}$ for $12 \mathrm{mi}$ nutes and the supernatants were transferred to new tubes containing $500 \mu \mathrm{L}$ of cold absolute ethanol. The tubes were shaken by hand, and the samples were again centrifuged at $20,000 \times g$ at $8^{\circ} \mathrm{C}$ for 12 minutes. The pellets were washed twice with $500 \mu \mathrm{L}$ of $70 \%$ ethanol, dried and resuspended in $30 \mu \mathrm{L}$ of Milli-Q water. Each sample was tested for DNA quantity, and protein and salt contamination via reading at OD 260/280 and 260/ 230 , respectively. DNA was re-extracted from samples that had ratios $<1.8$. Purified DNA was stored at $-20^{\circ} \mathrm{C}$ until further procedures were performed.

\section{PCR assay for rDNA ITS region amplification}

To amplify the rDNA ITS1, 5.8 S, and ITS2 regions, we performed PCR assays with the primer pair ITS1 and ITS4 at $10 \mathrm{pmol} / \mu \mathrm{L}$, in a final volume of $25 \mu \mathrm{L}$ containing: $12.5 \mu \mathrm{L}$ of PCR MasterMix (Promega, Madison, WI - USA), $2 \mu \mathrm{L}$ ITS1 primer (forward), $2 \mu \mathrm{L}$ of ITS4 primer (reverse), $2.5 \mu \mathrm{L}$ of $5 \% \mathrm{BSA}, 4 \mu \mathrm{L}$ of Milli$\mathrm{Q}$ water and $2 \mu \mathrm{L}$ of DNA sample. The thermal cycling protocol used was as follows: an initial denaturation phase of 5 minutes at $94^{\circ} \mathrm{C}$, followed by 35 cycles of $94^{\circ} \mathrm{C}$ for 1 minute, $58^{\circ} \mathrm{C}$ for 1 minute, $72^{\circ} \mathrm{C}$ for $2 \mathrm{mi}$ nutes, and finally an additional extension phase at $72^{\circ} \mathrm{C}$ for 10 minutes. Each PCR batch included one reaction containing Milli-Q water as a negative control and one reaction containing DNA extracted from C. albicans ATCC 24433 culture as a positive control.

The PCR samples were submitted to agarose gel electrophoresis to verify DNA amplification. When two or more amplicons were visualized on a gel, each band was purified using a GFX kit (GE Healthcare, UK), and each fragment was sequenced independently.

\section{ITS sequencing and yeast species identification}

The sequencing reaction was performed through the addition of $2 \mu \mathrm{L}$ of diluted amplicon (1:10 to intense bands, $1: 5$ to weak bands) to a reaction mix containing $2 \mu \mathrm{L}$ of BigDye Terminator (Applied Biosystems, USA), $4 \mu \mathrm{L}$ of sequencing buffer (Applied Biosystems, USA), $4 \mu \mathrm{L}$ of Milli-Q water and $3 \mu \mathrm{L}$ of $2 \mathrm{pmol} / \mu \mathrm{L}$ primer, in a total reaction volume of $15 \mu \mathrm{L}$. The reactions were submitted to 25 thermal cycles as follows: $95^{\circ} \mathrm{C}$ for 20 seconds, $50^{\circ} \mathrm{C}$ for 15 seconds and $60^{\circ} \mathrm{C}$ for 1 minute. The reactions were precipitated through the addition of $2 \mu \mathrm{L}$ of $3 \mathrm{M}$ sodium acetate/well, $2 \mu \mathrm{L}$ of $125 \mathrm{mM}$ EDTA/well and $55 \mu \mathrm{L}$ of ethanol per well and then denatured through the addition of $15 \mu \mathrm{L}$ of formamide HiDi (Applied Biosystems, USA) and incubation at $94^{\circ} \mathrm{C}$ for 4 minutes. Finally, the samples were rapidly cooled on ice before the reactions were run on the automatic sequencer.

The amplicons were sequenced using the Sanger methodology in a MicroAmp - Optical 96-well reaction plate (Applied Biosystems, USA) and the automatic sequencer ABI 3130 (Applied Biosystems, USA). At least 2 reads were generated for each sample.

The chromatograms generated by each sample were assembled into contigs and edited using the software programs Phred Phrap and Consed, respectively [37-40]. Alignments with $<100$ errors per $10 \mathrm{~Kb}$ were considered valid. The sequences were then compared to the NCBI genomic database using the BLASTn tool. Species identifications were accepted when the BLASTn values were e-value $<10^{-5}$ and identity $\geq 98 \%$ [41] 


\section{Performance evaluation of the PCR assay}

Species identification generated by our PCR method was compared to results obtained by the conventional culturebased identification method.

Putative assays with no PCR amplification were checked for the presence of PCR inhibitors through the addition of $C$. albicans ATCC genomic DNA.

\section{Ethics statement}

The protocol was approved by the Ethics Committee of the Federal University of Sao Paulo (n. 1414/09).

\section{Competing interests}

The authors declare that they have no competing interests.

\section{Authors' contributions}

HX carried out the molecular techniques, participated in the sequence alignment and drafted the manuscript. ASAM adapted and standardized the study methodology, assisted the data analysis and drafted the manuscript. AMM coordinated the sample selection for this study. MRSB contributed to the study design. ALC conceived and coordinated the study design and the draft of the manuscript. All authors read and approved the final manuscript.

\section{Acknowledgments}

Technical support in conventional species identification: Neide Ferreira Yonashiro and Vivian Pereira da Mota, from Central Laboratory of Hospital São Paulo.

Sequencing support: Dr. Ana Carolina B. Padovan, Dr. Angela S. Nishikaku. Clinical support in selecting patients for sample collection: Dr. Aline Pamela V. Oliveira, Dr. Maria Daniela Bergamasco, Dr. Ana Paula Jafet Ourives.

\section{Author details}

'Laboratório Especial de Micologia, Departamento de Medicina, Universidade Federal de São Paulo, Rua Pedro de Toledo 6695 andar, São Paulo, SP, Brazil. ${ }^{2}$ Laboratório de Genômica Evolutiva e Biocomplexidade, Departamento de Microbiologia, Imunologia e Parasitologia, Universidade Federal de São Paulo, Rua Pedro de Toledo 6694 andar, São Paulo, SP, Brazil. ${ }^{3}$ Laboratório Central do Hospital São Paulo, Rua Napoleão de Barros 7152 andar, São Paulo, SP, Brazil.

Received: 19 March 2013 Accepted: 26 September 2013 Published: 7 October 2013

\section{References}

1. Wenzel RP, Gennings C: Bloodstream infections due to Candida species in the intensive care unit: identifying especially high-risk patients to determine prevention strategies. Clin Infect Dis 2005, 41(Suppl 6):S389-S393.

2. Colombo AL, Thompson L, Graybill JR: The north and south of candidemia: issues for Latin America. Drugs Today 2008, 44:1-34. Suppl A

3. Antonelli M, Azoulay E, Bonten M, Chastre J, Citerio G, Conti G, Backer D, Lemaire $F$, Gerlach $H$, Hedenstierna $G$, et al: Year in review in Intensive Care Medicine 2009: I. Pneumonia and infections, sepsis, outcome, acute renal failure and acid base, nutrition and glycaemic control. Intensive Care Med 2010, 36(2):196-209.

4. Gudlaugsson O, Gillespie S, Lee K, Vande Berg J, Hu J, Messer S, Herwaldt L, Pfaller M, Diekema D: Attributable mortality of nosocomial candidemia, revisited. Clin Infect Dis 2003, 37(9):1172-1177.

5. Ellepola AN, Morrison CJ: Laboratory diagnosis of invasive candidiasis. J Microbiol 2005, 43:65-84. Spec No.

6. Morrell M, Fraser VJ, Kollef MH: Delaying the empiric treatment of Candida bloodstream infection until positive blood culture results are obtained: a potential risk factor for hospital mortality. Antimicrob Agents Chemother 2005, 49(9):3640-3645.

7. Lehmann LE, Hunfeld K-P, Emrich T, Haberhausen G, Wissing H, Hoeft A, Stüber F: A multiplex real-time PCR assay for rapid detection and differentiation of 25 bacterial and fungal pathogens from whole blood samples. Med Microbiol Immunol 2007, 197(3):313-324.
8. Charles PE, Dalle F, Aho S, Quenot J-P, Doise J-M, Aube H, Olsson N-O, Blettery B: Serum procalcitonin measurement contribution to the early diagnosis of candidemia in critically ill patients. Intensive Care Med 2006, 32(10):1577-1583.

9. Garey KW, Rege M, Pai MP, Mingo DE, Suda KJ, Turpin RS, Bearden DT: Time to initiation of fluconazole therapy impacts mortality in patients with candidemia: a multi-institutional study. Clin Infect Dis 2006, 43(1):25-31.

10. Fujita SI, Senda Y, Nakaguchi S, Hashimoto T: Multiplex PCR using internal transcribed spacer 1 and 2 regions for rapid detection and identification of yeast strains. J Clin Microbiol 2001, 39(10):3617-3622.

11. White PL, Linton CJ, Perry MD, Johnson EM, Barnes RA: The evolution and evaluation of a whole blood polymerase chain reaction assay for the detection of invasive aspergillosis in hematology patients in a routine clinical setting. Clin Infect Dis 2006, 42(4):479-486.

12. Maertens J, Deeren D, Dierickx D, Theunissen K: Preemptive antifungal therapy: still a way to go. Curr Opin Infect Dis 2006, 19(6):551-556.

13. Metwally L, Fairley DJ, Coyle PV, Hay RJ, Hedderwick S, McCloskey B, O'Neill HJ, Webb CH, McMullan R: Comparison of serum and whole-blood specimens for the detection of Candida DNA in critically ill, nonneutropenic patients. J Med Microbio/ 2008, 57(Pt 10):1269-1272.

14. Khlif M, Mary C, Sellami H, Sellami A, Dumon H, Ayadi A, Ranque S: Evaluation of nested and real-time PCR assays in the diagnosis of Candidaemia. Clin Microbiol Infect 2009, 15(7):656-661.

15. Lau A, Halliday C, Chen SC, Playford EG, Stanley K, Sorrell TC: Comparison of whole blood, serum, and plasma for early detection of candidemia by multiplex-tandem PCR. J Clin Microbiol 2010, 48(3):811-816.

16. Avni T, Leibovici L, Paul M: PCR diagnosis of invasive candidiasis: systematic review and meta-analysis. J Clin Microbiol 2011, 49(2):665-670

17. Maaroufi Y, Ahariz N, Husson M, Crokaert F: Comparison of different methods of isolation of DNA of commonly encountered Candida species and its quantitation by using a real-time PCR-based assay. J Clin Microbiol 2004, 42(7):3159-3163.

18. Fredricks DN, Smith C, Meier A: Comparison of six DNA extraction methods for recovery of fungal DNA as assessed by quantitative PCR J Clin Microbiol 2005, 43(10):5122-5128.

19. Van Burik JA, Myerson D, Schreckhise RW, Bowden RA: Panfungal PCR assay for detection of fungal infection in human blood specimens. J Clin Microbiol 1998, 36(5):1169-1175.

20. Haugland RA, Heckman JL, Wymer LJ: Evaluation of different methods fo the extraction of DNA from fungal conidia by quantitative competitive PCR analysis. J Microbiol Methods 1999, 37(2):165-176.

21. Sandhu GS, Kline BC, Stockman L, Roberts GD: Molecular probes for diagnosis of fungal infections. J Clin Microbiol 1995, 33(11):2913-2919.

22. Pfeiffer CD, Samsa GP, Schell WA, Reller LB, Perfect JR, Alexander BD: Quantitation of Candida CFU in initial positive blood cultures. J Clin Microbiol 2011, 49(8):2879-2883.

23. Leaw SN, Chang HC, Sun HF, Barton R, Bouchara JP, Chang TC: Identification of medically important yeast species by sequence analysis of the internal transcribed spacer regions. J Clin Microbio/ 2006, 44(3):693-699.

24. Al-Soud WA, Radstrom P: Purification and characterization of PCRinhibitory components in blood cells. J Clin Microbiol 2001, 39(2):485-493.

25. Kreader CA: Relief of amplification inhibition in PCR with bovine serum albumin or T4 gene 32 protein. Appl Environ Microbiol 1996, 62(3):1102-1106.

26. Maaroufi Y, De Bruyne JM, Duchateau V, Georgala A, Crokaert F: Early detection and identification of commonly encountered Candida species from simulated blood cultures by using a real-time PCR-based assay. J Mol Diagnostics: JMD 2004, 6(2):108-114.

27. White PL: Detection of seven Candida species using the Light-Cycler system. J Med Microbiol 2003, 52(3):229-238.

28. Bennett J: Is real-time polymerase chain reaction ready for real use in detecting candidemia? Clin Infect Dis 2008, 46(6):897-898.

29. Shin $J H$, Nolte FS, Morrison CJ: Rapid identification of Candida species in blood cultures by a clinically useful PCR method. J Clin Microbiol 1997, 35(6):1454-1459.

30. Chang HC, Leaw SN, Huang AH, Wu TL, Chang TC: Rapid identification of yeasts in positive blood cultures by a multiplex PCR method. J Clin Microbiol 2001, 39(10):3466-3471.

31. Lau A, Sorrell TC, Chen S, Stanley K, Iredell J, Halliday C: Multiplex tandem PCR: a novel platform for rapid detection and identification of fungal pathogens from blood culture specimens. J Clin Microbiol 2008, 46(9):3021-3027. 
32. Cerikcioglu N, Aksu B, Dal TD, Deniz U, Bilgen HS, Ozek E, Soyletir G: Seminested PCR for detection and identification of Candida species directly from blood culture bottles. New Microbiol 2010, 33(1):57-62.

33. Pryce TM, Palladino S, Price DM, Gardam DJ, Campbell PB, Christiansen KJ, Murray RJ: Rapid identification of fungal pathogens in BaCT/ALERT, $B A C T E C$, and BBL MGIT media using polymerase chain reaction and DNA sequencing of the internal transcribed spacer regions. Diagn Microbiol Infect Dis 2006, 54(4):289-297.

34. Quiles-Melero I, Garcia-Rodriguez J, Romero-Gomez MP, Gomez-Sanchez P, Mingorance J: Rapid identification of yeasts from positive blood culture bottles by pyrosequencing. Eur I Clin Microbiol Infect Dis 2011, 30(1):21-24.

35. Landlinger C, Baskova L, Preuner S, Willinger B, Buchta V, Lion T: Identification of fungal species by fragment length analysis of the internally transcribed spacer 2 region. Eur J Clin Microbiol Infect Dis 2009, 28(6):613-622

36. Nguyen MH, Wissel MC, Shields RK, Salomoni MA, Hao B, Press EG, Shields RM, Cheng S, Mitsani D, Vadnerkar A, et al: Performance of Candida real-time polymerase chain reaction, beta-D-glucan assay, and blood cultures in the diagnosis of invasive candidiasis. Clin Infect Dis 2012, 54(9):1240-1248.

37. Ewing B, Hillier L, Wendl MC, Green P: Base-calling of automated sequencer traces using phred. I. Accuracy assessment. Genome Res 1998, 8(3):175-185.

38. Ewing B, Green P: Base-calling of automated sequencer traces using phred. II. Error probabilities. Genome Res 1998, 8(3):186-194.

39. Gordon D, Abajian C, Green P: Consed: a graphical tool for sequence finishing. Genome Res 1998, 8(3):195-202.

40. Hall L, Wohlfiel S, Roberts GD: Experience with the MicroSeq D2 largesubunit ribosomal DNA sequencing kit for identification of commonly encountered, clinically important yeast species. J Clin Microbiol 2003, 41(11):5099-5102.

41. Balajee SA, Borman AM, Brandt ME, Cano J, Cuenca-Estrella M, Dannaoui E, Guarro J, Haase G, Kibbler CC, Meyer W, et al: Sequence-based identification of Aspergillus, fusarium, and mucorales species in the clinical mycology laboratory: where are we and where should we go from here? J Clin Microbiol 2009, 47(4):877-884.

doi:10.1186/1471-2334-13-467

Cite this article as: Xafranski et al:: A quick and low-cost PCR-based assay for Candida spp. identification in positive blood culture bottles. BMC Infectious Diseases 2013 13:467.

\section{Submit your next manuscript to BioMed Central and take full advantage of:}

- Convenient online submission

- Thorough peer review

- No space constraints or color figure charges

- Immediate publication on acceptance

- Inclusion in PubMed, CAS, Scopus and Google Scholar

- Research which is freely available for redistribution 